\title{
Duygudurum ve Anksiyete Bozukluklarında Psikonöroimmünolojik Süreçler ve Psikoterapi ile İlişkisi
}

\author{
Psychoneuroimmunological Processes in Mood and Anxiety Disorders and \\ Their Relation with Psychotherapy

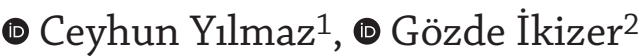 \\ 1İstanbul Medipol Üniversitesi, İstanbul, Türkiye \\ 2TOBB Ekonomi ve Teknoloji Üniversitesi, Ankara, Türkiye
}

Duygudurum ve anksiyete bozukluklarının yaygınlık oranlarının yüksekliği ve bu bozukluklarla ilişkili işlev bozuklukları nedeniyle, bu bozuklukların daha iyi anlaşılması, önlenmesi ve tedavi edilmesi oldukça önemlidir. Psikolojik ve diğer biyolojik nedensel faktörlerin ve mekanizmaların yanı sıra, inflamatuar biyobelirteçlerin, özellikle de sitokinlerin, duygudurum ve anksiyete bozukluklarının kökeninde ve sürdürülmesinde rolü olduğu kabul edilmektedir. Buradan hareketle, birtakım çalışmalar psikoterapi müdahalelerinin sitokin düzeylerinin de dahil olduğu nöroimmünolojik parametreler üzerindeki etkisine odaklanmıştır. Bu derleme, duygudurum ve anksiyete bozuklukları ve bunların sağaltımında yaygın olarak kullanılan psikoterapi yaklaşımları ile ilişkili psikonöroimmünolojik faktörlerden, özellikle sitokin düzeylerindeki değişimleri tartışmayı hedeflemektedir. Alanyazındaki çalışmaların çoğunda ilgili bozukluklar için psikoterapi alan bireylerde özellikle proinflamatuar sitokinlerin düzeylerinin azaldığı gösterilirken, anti-inflamatuar sitokinlerin düzeylerinin ise yükseldiği bildirilmiştir. Yine de çalışma desenlerinin çeşitliliği çalışmalar arasında bulguların kıyaslanmasında ve çalışmaların çoğunun kesitsel desene sahip olması psikiyatrik semptomatoloji ve immünolojik parametreler arasındaki neden-sonuç ilişkilerinin anlaşılmasında zorluk yaratmaktadır. Psikonöroimmünoloji alanında yapılacak gelecek çalışmalarda örneklem gruplarının ve ölçüm yöntemlerinin dikkatle belirlenmesi önemlidir. Ayrıca belirli psikoterapi yaklaşımlarının anti-inflamatuar etkileri olabileceğini gösteren bulguların bu yaklaşımlara özgü olup olmadığının anlaşılması için daha fazla sayıda psikoterapi sonuç çalışmasına ihtiyaç duyulmaktadır.

Anahtar Sözcükler: Duygudurum bozuklukları, inflamasyon, anksiyete bozuklukları, psikoterapi, sitokinler

Given high prevalence of mood and anxiety disorders and associated dysfunctions, better understanding, preventing, and treating these disorders are crucial. Along with psychological and other biological causal factors and mechanisms, inflammatory biomarkers, especially cytokines, have also been implicated in etiology and maintenance of mood and anxiety disorders. In the literature, it is generally acknowledged that there is a generalized inflammatory state in these disorders. Thus, several studies have focused on the impact of psychotherapy interventions on neuroimmunological parameters including cytokine levels. This review aims to discuss psychoneuroimmunological factors, especially changes in cytokine levels associated with mood and anxiety disorders and psychotherapy approaches which are commonly used for their treatment. Especially levels of pro-inflammatory cytokines have been shown in majority of those studies to be decreased while levels of anti-inflammatory cytokines have been reported to be elevated in individuals having psychotherapy for these disorders. Nevertheless, variability in study designs and cross-sectional designs in most studies create challenges for comparing results between studies and understanding cause-effect relationships between psychiatric symptomatology and immunological parameters. It is important to carefully determine sample groups and measurement methods in future studies in the field of psychoneuroimmunology. In addition, more studies are needed to figure out if findings showing that certain psychotherapeutic approaches can have anti-inflammatory effects are specific to those approaches or not.

Keywords: Anxiety disorders, mood disorders, cytokines, inflammation, psychotherapy

Yazışma Adresi/Address for Correspondence: Ceyhun Yılmaz, İstanbul Medipol Üniversitesi Sağlık Bilimleri Enstitüsü, İstanbul, Türkiye E-posta/E-mail: cey.yilmaz00@gmail.com Geliş tarihi/Received: 26.05.2021 Kabul tarihi/Accepted: 17.08.2021 ORCID ID: 0000-0003-2184-5881 
Duygudurum ve anksiyete bozuklukları küresel olarak yaygın psikiyatrik bozukluklar arasındadır. Türkiye'nin de dahil olduğu 204 ülkede ve bölgede gerçekleştirilen Küresel Hastalık Yükü 2019 (Global Burden of Disease Collaborative Network 2021) araştırmasının verilerine göre anksiyete bozuklukları (100 binde 3779.5) ile depresif bozuklukları (100 binde 3440.1) ve bipolar bozukluğu (100 binde 489.9) içeren duygudurum bozuklukları incelemeye konu olan diğer psikiyatrik bozukluklara kıyasla oldukça yüksek yaygınlık oranına sahip bozukluklar olarak görünmektedir. Yalnızca depresyonun dünyada 300 milyondan fazla insanı etkilediği ve 800 binden fazla bireyin özkıyım sonucu hayatını kaybetmesine neden olduğu; 300 milyona yakın insanın ise bir anksiyete bozukluğunun olduğu belirtilmektedir (World Health Organization 2017). Ülkemizde yapılan Ulusal Hastalık Yükü Çalışması 2013 (Çavlin 2017) bulgularına göre, depresif bozukluklar morbidite yükü en yüksek üç hastalıktan biri olarak belirlenmiştir. Anksiyete bozukluklarının özellikle majör depresif bozukluğa eşlik ettiği ve majör depresif bozukluğu olan bireylerin \%60'ı kadarının da yaşam boyu bir ya da daha fazla anksiyete bozukluğu için tanı ölçütlerini karşıladığı da bilindiğinden (Kaufman ve Charney 2000) bu bozuklukların alanyazında sıklıkla bir arada ele alındıkları görülmektedir (örn., Castle ve ark. 2006, Hofmann ve ark. 2012, Ressler ve Mayberg 2007). Hatta daha önce iki bozukluk kategorisinin tek bir duygusal bozukluk kategorisine indirgenmesi de önerilmiştir (Watson 2005). Duygudurum ve anksiyete bozuklukları kategorisinde yer alan bozuklukların neden olduğu işlev kaybı, küresel olarak işlev kaybına ve engele neden olan bozukluklar ve hastalıklar içinde ilk siralarda yer almaktadır (World Health Organization 2017). Bu bozuklukların yaygınlığı ve neden oldukları işlev kaybının boyutu göz önünde bulundurulduğunda bunların daha iyi anlaşılmasına, önlenmesine ya da tedavi edilmesine yönelik çabaların oldukça önemli olduğu anlaşılmaktadır.

Günümüzde duygudurum ve anksiyete bozukluklarının oluşum mekanizmaları hakkında birkaç başat hipotez (bkz. Craighead 2017) bulunmakla birlikte yeni yaklaşımlar arasında immünolojik yolaklar da dikkat çekmektedir. Özellikle bu bozuklukların ortaya çıkmasını ve seyrini etkileyebilecek immün değişkenlerle ilgili çalışmalar son yıllarda giderek artmaktadır (örn., Leonard 2010, Myint 2013). Alanyazında otoimmünite, sigara kullanımı, hava kirliliği, travma gibi çeşitli nedenlerle başlayabilen nöroinflamasyon sırasında yükselen sitokin düzeylerinin çeşitli mekanizmalarla psikiyatrik semptomatoloji ile ilişkili olabileceği belirtilmektedir (örn., Najjar ve ark. 2013). Olası mekanizmalar arasında inflamatuar sitokinlerin monoamin düzeyi üzerindeki doğrudan etkisi, hipotalamo-hipofizer-adrenal aks disregulasyonu, patolojik mikroglial hücre aktivasyonu, hasarlanmış nöroplastisite ve beyindeki bazı yapısal değişiklikler sayılmaktadır (Rosenblat ve ark. 2014). Ayrıca duygudurum ve anksiyete bozuklukları kategorilerinde yer alan bipolar bozukluk ile panik bozukluğun immün sistemdeki kalıtsal defektlerle ilişkili olabileceği de daha önce gösterilmiştir (Foldager ve ark. 2014). Yapılan çalışmalarda inflamasyonun etki boyutunun yeterince yüksek olduğu ve psikiyatrik bozuklukların inflamatuar biyobelirteçler kullanılarak birbirinden ayrıştırılabileceği dahi öne sürülmüştür (Yuan ve ark. 2019). Bu derlemenin temel amac1, duygudurum ve anksiyete bozuklukları ve bunların sağaltımında yaygın olarak kullanılan psikoterapi yaklaşımları ile ilişkili psikonöroimmünolojik faktörlerin, özellikle sitokin düzeylerindeki değişimlerin, tartışılmasıdır. Diğer bir deyişle makalede duygudurum bozukluklarının ve anksiyete bozuklukları ile ilişkili nöroinflamatuar mekanizmaların özetlenerek psikoterapötik müdahalelerin bu mekanizmalar üzerindeki etkisinin tartışılması hedeflenmektedir. Ayrıca bu makale bu bozukluklarda sık kullanılan psikoterapilerin sağaltıcı etkisinin, psikolojik iyilik halini desteklemeye ek olarak immün sistem üzerindeki anti-inflamatuar etkilerin bir sonucu olarak ortaya çıkıyor olabileceğine yönelik bulguları ve görüşleri gözden geçirmeyi hedeflemektedir. Duygudurum bozuklukları ve anksiyete bozukluklarına yönelik farmakolojik tedavilerin nöroimmünolojik süreçler ile ilişkisi daha önce incelenmiş olmakla birlikte (örn., Boorman ve ark. 2015, Hannestad ve ark. 2011, Vojvodic ve ark. 2019), psikoterapilerin inflamasyon ile ilişkisi yazarların bildiği kadarıyla daha önce herhangi bir kaynakta yeterince kapsamlı şekilde ele alınmamıştır.

\section{Psikiyatrik Bozukluklar ve İmmün Sistem}

Hayvan ve insan araştırmalarında davranışların ve duyguların immün işlevi nasıl etkileyebileceği önemli bir araştırma konusu olarak karşımıza çıkmaktadır. İlk kez 1964'te Solomon psikoimmünoloji terimini ortaya atmış olsa da 1980'lere dek bu alanda çok az sayıda insan araştırması olduğu dikkati çekmektedir (Kiecolt-Glaser ve ark. 2002). Geçtiğimiz 40 yılda araştırmalarına ağırlık verilen önemli bir interdisipliner alan olarak psikonöroimmünoloji, genelolaraksinir sisteminin immün sistemle karşılıklı etkileşimini ve zihinsel süreçlerin immün sistemin işlevini nasıl modüle ettiğini incelemektedir (Daruna 2012). Psikiyatri, sinirbilim, immünoloji, fizyoloji, genetik, farmakoloji, moleküler biyoloji, endokrinoloji ve psikoloji gibi bilim dallarının katkı sunmasıyla her geçen gün genişleyen bir alan yazına sahip olan psikonöroimmünolojinin kökenlerinin Psikolog Robert Ader ile immünolog Nicholas Cohen'in (1975) çalışmasına dayandığı düşünülmektedir. Ader ve Cohen, fareler üzerinde yaptıkları klasik koşullanma deneyinde immünsupresif etkili bir ilaç olan siklofosfamid uygulamasıyla birlikte koşullu uyarıcı olarak şekerli su kullanmışlardır. Koşullanan farelerde şekerli suyun tek başına sunulmasıyla birlikte kontrol grubuna göre anlamlı bir immünosupresyon izlenmesi merkezi sinir sisteminin immün sistemle ilişkili olduğunun ilk kanıtlarından biri sayılmıştır. İlerleyen yıllarda siklofosfomid tedavisi alan sistemik lupus eritematozus tanılı bir gencin benzer bir protokolle koşullanması sonucu elde edilen tedavi başarısını sunan bir vaka örneği benzer süreçlerin insanlar içinde geçerli olabileceği göstermesi açısından önemli bulunmuştur (Olness ve Ader 1992).

İmmün sistem, doğal veya kazanılmış olarak aktifleşen hücresel yanıt ve antikor döngüleri ile çalışan geniş ve karmaşık bir sistemdir (Klimov 2019). Bu sistemi ilgilendiren başlica hastalıklar otoimmün hastalıklar, alerjiler, immün yetmezlikler ve kanserlerdir. İmmün sistemi ilgilendiren patolojiler bununla 
sınırlı kalmayıp aslında vücutta gerçekleşen pek çok olayda bir immün yanıt oluşmaktadır. Fiziksel, biyolojik, kimyasal ya da psikolojik etkilerle oluşabilen bu immün yanıt inflamasyon olarak adlandırılmaktadır (Punchard ve ark. 2004). İmmün yanıtın sorumlusu olan kimyasal aracılar, sitokinler, vücutta başlıca bağışıklık sistemi hücreleri arasında olmak üzere hücreler arasında iletişimi sağlayan çözünebilir biyoaktif mediatörlerdir. Özellikle sitokin aktivitesinin psikomotor yavaşlama, yeme ve uyku bozuklukları gibi davranış değișiklikleri ve ayrıca psikopatolojilerin etiyolojisinde rolü olduğu düşünülen serotonin, dopamin ve norefinefrin gibi monoaminlerin metabolizmasındaki değişimler ile yakından ilişkili olduğu bilindiğinden (Dantzer ve ark. 1999a, 1999b) sitokinlerin sık görülen psikiyatrik bozukluklar ile ilişkisinin incelenmesinin bu bozukluklara yönelik bilinenlerin artırılması açısından yararlı olacağı düşünülmektedir.

Çoğunlukla immün aktivasyonun ya da hücre farklılaşması/ ölümünün aracısı olan sitokinler genel olarak pro-inflamatuar ve anti-inflamatuar şeklinde ikiye ayrılmaktadır (Klimov 2019). İnflamasyonun başlatıcısı rolündeki pro-inflamatuar sitokinlerin başlıcaları interlökin-1 (İL-1), interlökin-6 (İL-6), interlökin-12 (İL-12), tümör nekrozis faktör-alfa (TNF- $\alpha$ ) ve interferongamadır (IFN- $\gamma$ ). İnflamatuar yanıtı bastırmak için dengeleyici fonksiyonu olan anti-inflamatuar sitokinlerin başlicaları ise interlökin-4 (İL-4), interlökin-10 (İL-10), interlökin-13 (İL-13) ve alfa ve beta interferonlar (IFN- $\alpha$ ve İFN- $\beta$ )'dır (Klimov 2019). Beyin ve diğer merkezi sinir sistemi organları kan-beyin bariyeri sayesinde periferal immün yanıttan çoğunlukla etkilenmezken inflamasyonun merkezi sinir sisteminde görülmesi nöroinflamasyon olarak adlandırlır (Najjar ve ark 2013). Nöroinflamatuar süreçlerin Alzheimer hastalığı, Parkinson hastalığı, multipl skleroz ve AIDS ile ilişkili demans gibi birçok nörolojik hastalığın etiyolojisinde rol oynadığı bilinmektedir (örn., Anthony ve ark. 2005, Heneka ve ark. 2015, Hirsch ve ark. 2012, Rosenberg 2002). Tüm dünyadaki ölümlerde inflamasyon ile iliş̧kili hastalıkların önemli rolünün olduğu da daha önce vurgulanmıştır (GBD 2017 Causes of Death Collaborators 2018). $\mathrm{Bu}$ nedenle immün sistemle ilişkili olabilecek hastalıkların ve bozuklukların incelenmesi bunlara bağlı olarak ortaya çıkabilecek morbiditenin ve mortalitenin azaltılması açısından öneme sahiptir.

\section{Duygudurum Bozuklukları ile İlişkili Psikonöroimmünolojik Etkenler}

Alanyazında majör depresyonu açıklamaya yönelik stresli yaşam olayları, yatkınlık faktörleri, kişiler arası ilişkiler, çaresizlik ve umutsuzluk gibi çeşitli psikolojik faktörler (Hooley ve ark. 2017) mevcut olmakla birlikte biyolojik mekanizmalar da geniş kapsamlı şekilde incelenmiştir. Aday gen taramaları, nörotransmitter düzeyleri, nöroendokrinolojik akslar ve serebral kortekste morfolojik değişiklikler biyolojik modellerin konuları iken psikonöroimmünoloji öncülüğünde sistemik inflamasyona atıfta bulunan etiyolojik çalışmalar başlamıştır (Craighead 2017).
Majör depresyon için tartışlan inflamatuar etiyoloji temel olarak serotonerjik yıkım, endokrinolojik yolak, mikroglial süreçler ve beyinde morfolojik değişiklikler hakkındadır. Depresyonda proinflamatuar sitokinlerin ve akut-faz proteinlerinin düzeyinin artmasıyla düşük düzeyli bir inflamasyonun meydana geldiği düşünülmektedir (Euteneuer ve ark. 2017). Valkanova ve ark. (2013) tarafından gerçekleştirilen meta-analizlerde inflamatuar biyobelirteçlerin düzeylerinin artışının depresif epizodların öncesinde görüldüğü bulunmuştur. Sitokinlerin ve inflamasyonun artışı çeşitli belirtilere ve psikiyatrik bozukluklara yol açabilmektedir (Sözeri Varma, 2014). Alanyazında etiyolojik açıdan önemi olan birçok biyomekanizmadan söz edilmektedir. Bu kapsamda geniş kapsamlı çalışılan önemli bir yolak triptofan/ kinürenin yolağı ve indolamin 2,3-dioksijenaz (IDO) enzimi aktivitesidir. Triptofan aminoasidi, serotoninin öncül maddesi olup; serotonine alternatif bir yolak ile de immün sistem üzerinde önemli düzenleyici görev üstlenen kinürenine ve onun metabolitlerine dönüşür (Comai ve ark. 2016). İFN- $\alpha$ ve İFN- $\alpha$ ile sinerjistik çalışan birtakım sitokinler, triptofanın kinürenine dönüşümüne aracıllk eden İDO enziminin aktivitesini arttırmaktadır. Bu şekilde, beyinde var olan triptofan, kinürenin yolağı için daha fazla harcanmakta; serotonin sentezi için daha kısıtlı substrat (triptofan) kalmaktadır. Sitokin aracılı̆ııla indüklenen bu mekanizma ile azalan serotonin düzeyinin depresyona aracllık ettiği düşünülmektedir (Mándi ve Vécsei 2012).

Nörotransmisyon üzerine olan etkiler dışında; İL-1, İL-6, TNF- $\alpha$ ve İFN- $\alpha$ gibi sitokinlerin hipotalamik-pitüiter-adrenal eksenini etkinleştirdiği, kortikotropin serbestleştirici hormon (CRH), adrenokortikotropik hormon (ACTH) ve kortizol düzeylerinin arttığı ve böylece inflamasyonda rolü olduğu bilinmektedir (Beishuizen ve Thijs 2003). Kortizolün anti-inflamatuar etkisiyle bu eksenin negatif geribildirimle kontrol altında tutulması söz konusu iken kronik inflamasyonun neden olduğu sürekli kortizol uyarımı hormonun azalmış duyarllığı ve azalmış biyoulaşılabilirliği ile sonuçlanmaktadır (Raison ve Miller 2003). Kritik olan bir diğer mekanizma sinir sisteminin immün hücresi denilebilecek mikrogliaların aktivasyonudur. TNF- $\alpha$ ve İL-1 $\beta$ aracilığı ile aktive olan mikroglialar sinaptik budanmanın artışına ve nöronların programlı hücre ölümüne (apoptosise) girmesine yol açar. Bu durum ise bipolar bozuklukta ve majör depresif bozuklukta adaptif olmayan davranışların ortaya çıkmasına ve suboptimal beyin fonksiyonlarına (örn., dikkatte, yönetici işlevlerde ve sözel bellekte bozulma) aracllı etmektedir (Ekdahl 2012, Paradise ve ark. 2012, Park ve Bowers 2010, Stertz ve ark. 2013). İleri sürülen bir diğer mekanizma ise beyin yapisında meydana gelen anatomik ve fonksiyonel değişimlerdir. Kronik nöroinflamasyon sürecinde beyinde lateral ventriküllerin büyümesi, subgenual singulat kortekste değişimler ve mezolimbik bağlantılarda azalma duygudurum bozukluklarında rolü olduğu düşünülen değişimlerdir (Harrison ve ark. 2009).

Duygudurum bozukluklarının olası immün mekanizmalarını açıklayanbuönermelerçeşitlikesitselaraştırmalarilesınanmıştır. Dowlati ve ark. nın (2010) alanyazındaki 24 çalışmayı kapsayan meta-analizinin bulgularına göre majör depresif bozukluk tanısı 
alanların serum TNF- $\alpha$ ve İL-6 düzeyleri kontrol grubuna klyasla anlamlı derecede yüksektir. Aslan (2018) da majör depresyon tanısı olanlarda TNF- $\alpha$ ve İL-6 düzeylerinin sağlıklı kontrol grubundan yüksek olduğunu; tekrarlayan depresyonu olanlarda ise bu değerlerin ilk atak depresyonu olanlara kıyasla yüksek olduğunu bulmuştur. Yakın zamandaki çalışmalar da İL-6 düzeylerinin majör depresif bozukluğu olanlarda daha yüksek olduğu bulgusunu tekrarlamaktadır (Choi ve ark. 2021). Choi ve ark. (2021) TNF- $\alpha$ düzeylerinin depresyonu olanlarda intihar düşüncelerini yordayan bir belirteç olduğunu da göstermişlerdir. Krogh ve ark. (2014) 57'si kontrol grubunda yer alan toplam 112 katılımcı ile yaptıkları araştırmada majör depresif bozukluğu olanlarda İL-6 ve CRP düzeylerini daha yüksek bulmuşlardır. Norveç’te yürütülen başka bir çalışmada majör depresif bozukluk tanısı olan 50 birey, 34 sağlıklı kontrol ile karşılaştırılmış ve tanısı olanların serum İL-1 $\beta$, İL-5, İL-6, İL7, İL-8 ve İL-10 düzeyleri anlamlı ölçüde yüksek bulunmuştur (Dahl ve ark. 2014). Majör depresyonun alt türlerine göre inflamatuar aktivitenin değişebileceğini öne süren çalışmalar da mevcuttur. 35'i atipik depresyonu olan 105 majör depresyonlu bireyden alınan örneklerde atipik depresyonu olanlarda İL-2 düzeyleri artmış ancak İL-4 düzeyleri azalmış olarak bulunmuştur. İL-6 ve TNF- $\alpha$ düzeylerinde anlamlı bir değişim gözlenmezken bu durum lökosit alt tiplerindeki dağılımın farklılığı ile açıklanmıştır (Yoon ve ark. 2012). Son olarak dikkat çeken bir diğer çalı̧̧mada ise depresyonda bilişsel ya da bedensel semptomatolojinin inflamasyon ile farklı şekilde bağlantılı olduğu ileri sürülmüştür (Duivis ve ark. 2013). 2861 katılımcıll, çok merkezli bu çalışmada depresyonun bedensel belirtilerinin şiddetinin inflamasyon belirteçlerinden CRP, İL- 6 ve TNF- $\alpha$ düzeylerindeki yükselmeyle ilişkili olduğu yalnız bilişsel belirtiler için bu ilişkinin mevcut olmadığı bulunmuştur.

Bipolar bozukluk ise oluşum mekanizması henüz tam aydınlatılmamış bir diğer duygudurum bozukluğu olmakla birlikte bozukluğun nöroprogresyonu immün disfonksiyon, artmış oksidatif stres ve nörotropik desteğin azalması ile ilişkilendirildiği ve bozukluğa sahip bireylerde birtakım otoimmün hastalıkların (örn., SLE, otoimmün hepatit, otoimmün tiroidit, MS) insidansının arttığı görülmektedir (Barbosa ve ark. 2014). Kalelioğlu ve ark. (2017) gerçekleştirdikleri derlemenin sonucunda alanyazındaki çalışmalarda genellikle atak dönemlerinde sitokin düzeylerinde artış görülmekle birlikte, her sitokinin farklı davranıyor olabileceğini belirtmişlerdir. Alanyazındaki çalışmalar da bozukluğun farklı epizodlarında ya da evrelerinde sitokin düzeylerinin farklılaştığını ortaya koymaktadır. Altamura ve ark. (2014) alanyazındaki bulgular incelendiğinde, depresif epizodlar sirasinda İL-8, CRP ve TNF- $\alpha$ gibi proinflamatuar sitokinlerin, manik epizodlar sırasında ise İL-6, İL-8 ve TNF- $\alpha$ düzeylerinin arttığını; İL-4 için ise tutarlı olmayan sonuçlar olduğunu belirtmişlerdir. Bu çalışmalar incelendiğinde, örneğin, Brietzke ve ark. nın (2009) yaptığı bir çalışmada bipolar bozukluğu olanlar veri toplama sırasında ötimik, manik ve depresif epizod tanı ölçütlerini karşılayıp karşılamadıkları temelinde farklı gruplara ayrıştırılarak kontrol grubuyla karşılaştıılmışlardır. Bulgulara göre ötimik olanlarda yalnızca İL-4 düzeylerinde artış tespit edilirken; manik epizodda İL-2, İL-4 ve İL-6, depresif epizodda ise yalnızca İL-6 düzeyleri artmıştır. Bu açıdan, bipolar bozukluğun depresif epizodunun majör depresif bozukluk ile ortak patofizyolojik mekanizmalara sahip olmasına karşın manik epizodların bunlardan ayrıldığı belirtilmiştir. Bipolar I bozukluk tanısı almış 60 birey erken ve geç evre olarak iki gruba ayrılıp 60 katılımcıdan oluşan sağlıklı kontrol grubuyla karşılaştırıldığı bir çalışmada ise, erken evre bipolar bozukluğa sahip bireylerde İL-6, İL-10 ve TNF- $\alpha$; geç evre bozukluğu olanlarda ise İL-10 ve TNF- $\alpha$ düzeyleri kontrol grubuna göre anlamlı olarak yüksek bulunmuştur (KauerSant'Anna ve ark. 2009). Benzer şekilde, bipolar bozukluğu olanların kronik ya da erken evre olarak iki gruba ayrıldığ başka bir çalı̧̧mada ise kronik bozukluğu olanların erken evre ve sağllklı kontrol gruplarına oranla daha yüksek TNF- $\alpha$ ve İL-6 düzeylerine sahip oldukları görülmüştür (Karabulut ve ark. 2019). Buna karşın bipolar bozukluğu olanlarda yapılan bir çalışmada ise bozukluğu olanların kontrollere kıyasla ve ayrıca bozukluğun alt tiplerine sahip bireyler arasında periferik inflamatuar belirteçler (IL-2, IL-4, IL-8, IL-10 ve TNF $\alpha$ ) açısından anlamlı fark bulunmamıştır (Özen ve ark. 2019).

Bu bulgular bir arada düşünüldüğünde duygudurum bozukluğu tanısı alan bireylerde sağlıklı kontrollere göre sistemik inflamasyonun belirteci olan sitokin düzeylerinin anlamlı derecede yüksek olduğu görülmektedir. Yükselen sitokin düzeyleri ise farklı biyolojik mekanizmalarla psikopatolojinin oluşumuna ve seyrine katkıda bulunabileceği düşünülmektedir.

\section{Anksiyete Bozuklukları ile İlişkili Psikonöroimmünolojik Etkenler}

Anksiyete bozukluklarını duygudurum bozuklukları ile yüksek oranda komorbid olması (Kaufman ve Charney 2000) etiyolojilerini ayriştırmakta güçlük yaratsa da bu bozukluklara yatkınlığa neden olan etkenlerin genetik temel ve antenatal gelişim özelliklerinden başlayarak mizaç, olumsuz çocukluk deneyimleri ve model almaya kadar geniş bir aralıkta çeşitlilik gösterdiği bilinmektedir (Manassis ve Bradley 1994). Yakın zamandaki çalışmalar anksiyete bozukluklarının anlaşılmasında oksidatif stresin de önemini vurgulamaktadır (Fedoce ve ark. 2018). Düzeyi artan pro-inflamatuar sitokinler, vücutta serbest oksijen radikallerini düzenleyen enzimleri kontrol eden inflamasyon ile ilişkili transkripsiyon faktörlerini aktive etmektedir. Böylelikle artan oksidatif stres, hücrelerde mitokondriyal disfonksiyon yaratarak ve telomer kısalmasını hızlandırarak nörogenezi ketlemektedir. Pro-inflamatuar sitokinlerin artışının bir başka etkisi ise nöronal sinyalleri bozarak glutamat artışıly nöronal toksisite oluşturması ve GABA aktivitesini azaltarak anksiyojenik etkiye sahip olmasıdır (Hovatta ve ark. 2010). GABA aktivitesinin azalması anksiyete bozukluklarının geneli için önemli bir etiyolojik etkendir (Craighead, 2017). Sonuç olarak, oksidatif mekanizmalardaki değişimlerin psikiyatrik bozuklukların patofizyolojisinden sorumlu olabileceği düşünülmektedir (Vismara ve ark. 2020). Vismara ve ark. (2020) HPA ekseninin ve otonom sinir sisteminin aracllık ettiği stres yanıtı mekanizmalarının ve inflamasyon 
arasındaki ilişkinin anksiyete bozuklukları için önemli olduğunu belirtmektedir. Özellikle epinefrin ve norepinefrin hormonları sitokin salınımı ile doğrudan ilişkilidir. Bu açıdan anksiyete bozuklukları ile ilişkili psikonöroimmünolojik etkenlerin anlaşılmasına yönelik çabaların önemli olduğu açıktır. Bununla birlikte Ruhsal Bozuklukların Tanısal ve İstatistiksel El Kitabının son versiyonundaki (DSM-5; American Psychiatric Association [APA] 2013) tüm bozukluk kategorileri içinde en yaygın görülen kategori olmasına (Bandelow ve Michaelis 2015) rağmen anksiyete bozukluklarında immünolojik parametrelerdeki değişimi araştıran kısıtlı sayıda çalışma mevcuttur. Bu derlemeye dahil edilen çalışmaların sayısının kısıtlı olmalarının bir nedeni hakkında görece daha fazla sayıda çalışma bulunan travma sonrası stres bozukluğunun ve obsesif-kompülsif bozukluğunun DSM5'te (APA 2013) anksiyete bozuklukları kategorisinden çıkarılmış olmasıdır. Bir diğer nedeni ise çalışmaların bir bölümünün (örn., Duivis ve ark. 2013, Lee 2020, Liukkonen ve ark. 2011) anksiyete bozukluğu olan bireylerde değil, genel toplumda anksiyete ölçümleri kullanılması ve anksiyete puanlarının immünolojik parametreler ile ilişkisinin incelenmesi yoluyla yapılmış olmasıdır.

Yine de mevcut çalı̧malar anksiyete bozukluğu tanılı bireylerde anlamlı immünolojik değişimlerin olduğunu ortaya koymaktadır. Örneğin, aralarında sürmekte olan ya da geçirilmiş yaygın anksiyete bozukluğu, sosyal anksiyete bozukluğu, panik bozukluk veya agorafobisi olan katılımcıların dahil olduğu 556's kontrol grubundaki toplam 2288 katılımcilı bir kohort çalışmasında (Vogelzangs ve ark. 2013), CRP, İL-6 ve TNF- $\alpha$ düzeyleri incelenmiştir. Anksiyete bozukluğu olan erkeklerin CRP düzeyleri kontrollere kıyasla anlamlı ölçüde yüksek bulunurken, geç başlangıçlı (50 yaş ve sonrası) anksiyete bozukluklarında da CRP düzeylerinin benzer şekilde yüksek olduğu görülmüştür. Wagner ve ark. (2015) ise agorafobisi olanlarda CRP ve TNF- $\alpha$ düzeylerinde artı̧̧ olduğunu göstermişlerdir. Costello ve ark. (2019) gerçekleştirdikleri sistematik derleme ve metaanaliz çalışmasında yaygın anksiyete bozukluğunda sağlıklı kontrollere kıyasla CRP, İFN- $\gamma$ ve TNF- $\alpha$ düzeylerinin arttığını belirlemişlerdir. Zou ve ark. (2020) da İFN- $\gamma$ düzeylerinin yaygın anksiyete bozukluğunda anksiyetenin şiddetiyle pozitif ilişkili olduğunu da ortaya koymuştur. Aynı çalışmada, IL-6 düzeyleri benzer şekilde yaygın anksiyete bozukluğu olanlarda da yüksek gözlenmiştir. Ancak IL-6 düzeylerinin anksiyeteyle birlikte artmasına rağmen, bu biyobelirteçin artmış düzeylerinin altı yıl sonra anksiyete belirtilerini yordamadığı gösterilmiştir (Lee 2020).

Anksiyete bozuklukları kategorisinde panik bozukluğu ile ilgili çalışmaların sayısı görece fazladır. Örneğin panik bozukluğu olan bireylerle yapılan bir çalışmada İFN- $\gamma$ ve IL12 düzeylerinin düştüğü bulunmuştur (Tükel ve ark. 2012). Petrowski ve ark. (2018) da panik bozukluğa sahip hastalarda başlangıçta ve psikososyal stres şartlarında anti-inflamatuar aktivitenin arttığını göstermişlerdir. Hoge ve ark. (2009) daha önce İL-6'ya ek olarak İL-1 $\beta$ ve TNF- $\alpha$ düzeylerinin de arttığını göstermiştir. Yakın zamandaki bir çalışmada da benzer şekilde panik bozukluğu olanlarda sağlıklı kontrollere kıyasla IL-6 düzeylerinin yüksek olduğu bulunmuştur (Choi ve ark. 2021).
Panik bozukluğunda sitokinlerin rolüne ilişkin bir sistematik derlemede panik bozukluğu olanlarda İL-6, İL-1 $\beta$ ve İL-5 düzeylerinin çalışmalarda tutarlı şekilde yüksek olduğunun gösterildiği ancak IL-2, IL-12 ve INF- $\gamma$ ile ilgili tutarlı olmayan bulguların olduğu bildirilmiştir (Quagliato ve Nardi 2018).

Özetle, alanyazın incelendiğinde anksiyete bozukluklarında inflamatuar biyobelirteçlerin özellikle panik bozukluğu, yaygın anksiyete bozukluğu ve sosyal anksiyete bozukluğu bağlamında incelendiği görülmektedir. DSM-5'te (APA 2013) diğer anksiyete bozuklukları (örn., özgül fobi, ayrılma anksiyetesi bozukluğu) ile ilgili çalışmalara rastlanmamıştır. Özellikle panik bozukluğu ile ilgili alanyazındaki çelişkili bulguların biyobelirteçlerin ölçümündeki ve örneklemlerdeki farklllıklar ile ilgili olduğu öne sürülmektedir (Quagliato ve Nardi 2018). Buna ek olarak, bu makalede sözü edilen sitokin düzeyi artışlarının anksiyete bozukluklarının etiyolojisinde nasıl rol oynadığının araştırılması önerilmektedir (Costello ve ark. 2019). Özellikle belirli biyobelirteçlerin (örn., Tip-I [İFN-alfa, İFN-beta] ve Tip-II [IFN- $\gamma]$ interferonlar) birbirlerine antagonist çalışıyor olabilecekleri de daha önce öne sürülmüştür (bkz. Deczkowska ve ark. 2016). Çelişkili bulguların daha iyi anlaşılmasında bu tür olası mekanizmalara çalışmalarda daha fazla odaklanılmasının ve çalışma desenlerinin bulguların kıyaslanmasına olanak sağlayacak şekilde oluşturulmasının önemli olduğu düşünülmektedir.

\section{Duygudurum ve Anksiyete Bozukluklarında Psikoterapilerin İmmünolojik Etkenlerle İlişkisi}

Çeşitli psikiyatrik bozuklukları ve duygusal zorlukları olan bireylere yardımcı olmanın bir yolu olan psikoterapilerin belirtilerde iyileşmeye ve işlev düzeyinde artışa katkı sağladığı bilinmektedir (Parekh ve Givon 2019). Psikoterapi çeşitli psikopatolojilerde oldukça sık kullanılan bir tedavi yolu olmakla birlikte farmakolojik tedaviler ile kıyaslandığında ilişkili biyolojik mekanizmalar hakkında çalışmalar kısıtlıdır (Etkin ve ark. 2005). Öyle ki psikoterapilerin neden olduğu biyolojik değişimlerin farmakoterapiler ile ilişkili değişimlerden farklı olduğu da kabul edilmektedir (Fuchs 2004). Bu da yaygın görülen bozukluklarda kullanılan psikoterapi yaklaşımları ile ilişkili olabilecek değişimlerin ele alınmasının önemini ortaya koymaktadır.

Alanyazında psikiyatrik bozukluklara yönelik başarılı psikoterapi müdahaleleri sonrasinda ortaya çıkan nöral ve/veya epigenetik değişimlere yönelik kanıtlar bulunmaktadır. Örneğin depresyona ve anksiyete bozukluklarına yönelik psikoterapilerde duygu düzenleme ile ilişkili nöral değişimler arasında dorsomedial prefrontal korteks, posterior singulat girus/precuneus ve temporal lobda belirli bölgelerde (Messina ve ark. 2013) ve sağ parasingulat girusta (Kalsi ve ark. 2017) değişimler izlendiği daha önce bildirilmiştir. Ayrıca majör depresif bozukluğa yönelik psikoterapi alanlarda sol amigdala, sol hipokampüs ve subgenual anterior singulat kortekste nöral aktivitede değişimler olduğu da bulunmuştur (Straub ve ark. 2015). Bunlara ek olarak, başarıyla sonuçlanan psikoterapi müdahaleleri sonrasında gözlenen DNA 
ya da histon değişimleri gibi epigenetik değişimlerin gelecek nesillere aktarılabileceği ve bunun da belirli bozuklukların önlenmesine katkı sağlayabileceği belirtilmiştir (Schiele ve ark. 2020).

Psikoterapilerin yukarıda belirtilen değişimlere ek olarak çeşitli immünolojik parametrelerdeki değişimle ilişkisine yönelik alanyazın kısıtlıdır. Bununla birlikte, psikonöroimmünoloji alanındaki müdahale çalışmalarında çeşitli örneklemlerde hipnoz, gevşeme, egzersiz, klasik koşullanma, kendini açma, maruz bırakma tekniklerini ve bilişsel davranış̧̧ı terapiyi (BDT) içeren farklı stratejiler üzerinde durulmuştur (Kiecolt-Glaser ve Glaser 1992). Duygudurum ve anksiyete bozukluklarında da yukarıda sözü edilen birçok psikoterapi tekniği sıklıkla kullanılmaktadır. Amerikan Psikoloji Birliği'nin (2021) majör depresyon için bilişsel terapi, BDT, kabul ve kararlılık terapisi, duygu odaklı terapi, kısa süreli psikodinamik terapi gibi birçok kanıta dayalı terapiyi önerdiği; bipolar bozukluk için ise bilişsel terapi, aile odaklı terapi, kişilerarası ve sosyal ritim terapisi, psikoeğitim ve sistematik bakımı önerdiği görülmektedir. Aynı kaynakta anksiyete bozukluklarının psikolojik tedavisi için aşamalı gevşeme, BDT, psikanalitik terapi, maruz bırakma terapileri gibi çeşitli psikoterapi yaklaşımlarının kanıta dayalı psikolojik tedaviler arasında sunulduğu görülmektedir. Yakın zamandaki bir meta-analiz çalışmasında bilişsel terapi, davranış terapisi ya da BDT ve benzeri müdahalelerin otoimmün bozukluk, kanser, HIV, insomnia, stres ve depresyon gibi hastalıkları ya da bozuklukları olanlarda genel olarak zaman içinde immün sistem işlevinde iyileşme ile ilişkili olduğuna dair kanıtlar sunulmuştur (Shields ve ark. 2020). Bununla birlikte Lopresti (2017) özellikle BDT ve inflamasyon arasındaki ilişkinin tek yönlü ele alınmaması gerektiğini vurgulamıştır. Buna göre, terapinin anti-inflamatuar etkileri olduğu gibi inflamasyon düzeyinin yüksek olduğu danışan gruplarında inflamasyon tedavi yanıtını etkilemektedir.

Alanyazındaki çalışmalar daha ayrıntılı incelendiğinde, bu bozukluklara yönelik psikoterapi alan bazı bireylerde immünolojik parametrelerde olumlu nitelendirilebilecek değişimler olduğu görülmektedir. Örneğin, majör depresif bozukluğu olan 97 bireyin dahil olduğu bir çalışmada BDT'nin serum İL-6 ve TNF- $\alpha$ düzeylerinde anlamlı düşüş sağladığı ve bu düşüşün öyküleyici bilişsel terapi sonrası düşüşten daha fazla olduğu gösterilmiştir (Moreira ve ark. 2015). Walsh ve ark. (2016) depresif belirtileri olan 64 kadınla yaptıkları çalışmada dört haftalık farkındalık temelli müdahale sonrasinda tedavi grubunun kontrol grubuna göre tükürük İL-6 ve TNF- $\alpha$ düzeylerinde anlamlı düşme olduğunu bulmuşlardır. Benzer şekilde Del Grande da Silva ve ark. (2016) da majör depresif bozukluk tanısı olan 46 katılımcıya sundukları 18 seanslik destekleyici-ifade edici dinamik psikoterapi sonrası serum İL- 6 ve TNF- $\alpha$ düzeylerinde anlamlı düşüş olduğunu tespit etmişlerdir. Bir diğer çalışmada (Eisendrath ve ark. 2016) ise majör depresif bozukluk tanısı almış 11 kişilik bir gruba uygulanan sekiz haftalık farkındalık temelli bilişsel terapinin sonrasında CRP düzeylerinde anlamlı azalma kaydedilmiştir. Majör depresif bozukluk tanısı almış 50 katılımcı ile gerçekleştirilen boylamsal bir çalışmada ise olağan tedavi şemasında ilaç tedavisi olmadan yalnızca BDT uygulamaları ile kombine edilmiş 12 haftalık ilişkisel psikodinamik terapi gören 29 bireyin sitokin düzeyleri kontrol edilmiştir. Bu grupta İL6 , İL-10, İFN- $\gamma$ ve TNF- $\alpha$ düzeylerinin psikoterapi sonrasinda anlamlı şekilde azalarak kontrol grubu katılımcıları ile aynı düzeye geldiği bildirilmiştir (Dahl ve ark. 2016). Euteneuer ve ark. (2017) tarafından gerçekleştirilen çalı̧̧mada ise fiziksel egzersizin vurgulandığı bir davranış aktivasyonu tedavisi alan depresyon tanılı katılımcilarda aktif ve pasif kontrol gruplarına kıyasla anti-inflamatuar bir sitokin olan İL-10'un düzeyinde artış olduğu bulunmuştur. İlk epizod majör depresif bozukluk tanısı olan katılımcılarla yapılan çalışmalar ise tutarlı olmayan bulgular ortaya konmuştur. Bu çalışmalardan birinde (Gazal ve ark. 2013) yedi haftalık BDT sonrasında İL-6 düzeylerinin azaldığı ancak bir başka çalışmada (Keri ve ark. 2014) 16 haftalık BDT sonrasında İL-6 ve CRP düzeylerinde değişim olmadığı görülmüştür.

Psikonöroimmünoloji alanında majör depresif bozukluğa kıyasla bipolar bozuklukla ve anksiyete bozukluklarıyla ilgili çok daha az sayıda çalışma bulunmaktadır. Bipolar II bozukluğu tanısı olan 27 bireye ketiapin $(n=10)$ veya plasebo $(n=17)$ ile 20 haftalık kişilerarası ilişkiler ve sosyal ritim terapisi uygulanan bir çalş̧mada, psikoterapi ile ilaç tedavisi alan grupta İL-6 ve TNF- $\alpha$ düzeyleri artarken, yalnızca psikoterapi alan grupta İL-6 ve TNF- $\alpha$ düzeylerinde düşüş bulunmuştur (Fiedorowicz 2019). Anksiyete bozukluklarında kullanılan psikoterapi yaklaşımlarının sitokinler üzerinde etkili olduğunu gösteren tek çalışma ise Hoge ve ark. (2018) tarafından gerçekleştirilmiştir. Bu çalışmada, yaygın anksiyete bozukluğu tanısı alanların İL- 6 ve TNF- $\alpha$ düzeyleri farkındalık temelli bir müdahale sonrasında başlangıca göre anlamlı ölçüde azalmıştır.

$\mathrm{Bu}$ bulgular bir arada düşünüldüğünde, alanyazındaki çalışmaların bulguları genel olarak BDT, ilişkisel psikodinamik terapi, davranış aktivasyonu, farkındalık temelli müdahaleler, kişilerarası ilişkiler ve sosyal ritim terapisi, destekleyici dinamik psikoterapi yaklaşımlarının duygudurum ve birtakım anksiyete bozukluklarında kullanıldığında bu bozukluklardaki immünolojik parametrelerde iyileşme sağlayabileceği ve olası değişimleri tersine döndürebileceği izlenimi edinilmektedir. Yine de özellikle bipolar bozukluklar ve anksiyete bozuklukları hakkında yeterli çalışma olmadığı açıktır.

Psikoterapilerin immünolojik parametrelerde değişimler ile ilişkili olduğunu gösteren çalışmalara rağmen, alanyazında psikoterapilerin bu türde bir değişim ile ilişkili olmadığını ortaya koyan çeşitli çalışmalar da yer almaktadır. Örneğin Memon ve ark. (2017) depresyon ve anksiyete belirtileri olan bireyler üzerinden yürüttükleri çalışmalarında farkındalık temelli grup terapisi ve BDT uyguladıkları iki ayrı grupta da tedavi öncesi ve sonrası test edilen İL-6, İL-8 ve CRP düzeylerinde bir fark gözlemlememişlerdir. Bunu inflamatuar sitokin düzeylerindeki artışın depresyonun sonucu yerine beyin işlevinde depresyonla ilişkili değişimlerin bir sonucu olabileceğini ve bu nedenle tedaviye yanıtla ilişkili olmayabileceği şeklinde açıklamışlardır. Özellikle CRP düzeylerinin geç başlangıçlı depresyon ya da kadın cinsiyeti gibi belirli özelliklerle ilişkili olabileceği de belirtilmiştir (Memon 
ve ark. 2017). Yüksek CRP düzeyinin depresif belirtilere yönelik psikoterapilerde olumsuz sonucu yordadığı (Harley ve ark. 2010) da bilindiğinden CRP düzeylerindeki değişim ile ilgili çalışmalarda belirli alt gruplara yönelinmesi önerilmektedir. Koh ve Lee (2004) de panik bozukluğu olanlarla yaptıkları çalısmada BDT'nin anksiyolitik bir ilaçla birlikte verildiği koşulda İL-2 düzeyinde bir farklılık olmadığını göstermiştir. Kanser tedavisi görmekte olan gruplara depresif belirtiler ve anksiyete belirtilerine yönelik uygulanan müzik destekli psikoterapi (Zeppegno ve ark. 2021) sonrasında da sitokin düzeylerinde değişim olmadığı görülmüş; bu bulguları açıklamada immünoterapinin psikopatolojilerdeki rolünü anlamanın önemli olduğu belirtilmiştir. Bu bağlamda immün sistem ile ilişkili fiziksel hastalıkların tedavisinde kullanılan yöntemlerin psikonöroimmünoloji alanındaki psikoterapi sonuç çalı̧̧malarında karıştırıcı bir değişken olabileceği göz önünde bulundurularak çalışma örneklemlerinin oluşturulması önemli görünmektedir.

Özetle, psikoterapilerin immün sistemdeki değişimlerle ilişkisini inceleyen çalışmalar çeşitli psikiyatrik bozuklukları olan bireylerin belirtilerinin şiddetinde azalma ile iliş̧kili biyobelirteçlere odaklanmışlardır. Makalede sunulan bulgular Tablo 1'de özetlenmektedir. Bu makalelerdeki biyobelirteçler genellikle İL-6, İL-8, İL-10, TNF- $\alpha$ ve İFN- $\gamma$ olmakla birlikte az sayıdaki çalışmada CRP düzeylerinin de ölçüldüğü görülmektedir. Diğer bir deyişle psikoterapi sonuç çalışmalarının birçoğunda çalışmalara dahil edilen pro-inflamatuar biyobelirteçlerin düzeylerinde azalma olduğu bulunmaktadır. Az sayıdaki çalışmada ise, olasılıkla örneklem özelliklerine bağlı olarak, immünolojik parametrelerde değişim gözlenmemiştir. Bununla

\begin{tabular}{|c|c|c|c|}
\hline Kaynak & Örneklem & Müdahale & Etki \\
\hline \multicolumn{4}{|c|}{ Psikoterapi sonrası sitokin düzeylerinde anlamlı değişiklik gösterilen çalışmalar } \\
\hline Moreira ve ark. 2015 & Majör depresif bozukluk & BDT & $\begin{array}{l}\text { İL-6 } \downarrow \\
\text { TNF- } \alpha \downarrow\end{array}$ \\
\hline Walsh ve ark. 2016 & Depresif belirtiler & Farkındalık temelli müdahale & $\begin{array}{l}\text { İL-6 } \downarrow \\
\text { TNF- } \alpha \downarrow\end{array}$ \\
\hline Del Grande da Silva ve ark. 2016 & Majör depresif bozukluk & $\begin{array}{l}\text { Destekleyici-ifade edici dinamik } \\
\text { psikoterapi }\end{array}$ & $\begin{array}{l}\text { İL-6 } \downarrow \\
\text { TNF- } \alpha \downarrow\end{array}$ \\
\hline Eisendrath ve ark. 2016 & Majör depresif bozukluk & Farkındalık temelli BT & $\mathrm{CRP} \downarrow$ \\
\hline Dahl ve ark. 2016 & Majör depresif bozukluk & $\begin{array}{l}\text { BDT ile kombine edilmiş ilişkisel } \\
\text { psikodinamik terapi }\end{array}$ & $\begin{array}{l}\text { İL-5 } \downarrow \\
\text { İL-8 } \downarrow \\
\text { İL-6 } \downarrow \\
\text { İL-10 } \downarrow \\
\text { TNF- } \alpha \downarrow \\
\text { İFN- } \gamma \downarrow\end{array}$ \\
\hline Euteneuer ve ark. 2017 & Majör depresif bozukluk & Davranış aktivasyonu & İL-10 $\uparrow$ \\
\hline Gazal ve ark. 2013 & Majör depresif bozukluk & BDT & İL-6 $\downarrow$ \\
\hline Fiedorowicz 2019 & Bipolar II bozukluk & $\begin{array}{l}\text { Kişilerarass ilişkiler ve sosyal ritim } \\
\text { terapisi (+ ketiapin ya da plasebo) }\end{array}$ & $\begin{array}{l}\text { İL-6 } \downarrow \\
\text { TNF- } \alpha \downarrow\end{array}$ \\
\hline Hoge ve ark. 2018 & Yaygın anksiyete bozukluğu & Farkındalık temelli müdahale & $\begin{array}{l}\text { İL-6 } \downarrow \\
\text { TNF- } \alpha \downarrow\end{array}$ \\
\hline \multicolumn{4}{|c|}{ Psikoterapi sonrası sitokin düzeylerinde anlamlı değişiklik gösterilmeyen çalışmalar } \\
\hline Keri ve ark. 2014 & Majör depresif bozukluk & BDT & $\begin{array}{l}\text { İL-6 } \leftrightarrow \\
\text { CRP } \leftrightarrow\end{array}$ \\
\hline Memon ve ark. 2017 & $\begin{array}{l}\text { Depresif belirtiler/anksiyete } \\
\text { belirtileri }\end{array}$ & $\begin{array}{l}\text { Farkindalık temelli grup terapisi ya da } \\
\text { BDT }\end{array}$ & $\begin{array}{l}\text { İL-8 } \\
\text { CRP } \leftrightarrow \\
\text { CRP } \leftrightarrow\end{array}$ \\
\hline Referans & Örneklem & Müdahale & Etki \\
\hline Koh ve Lee 2004 & Panik bozukluk & $\begin{array}{l}\text { BDT (farmakoterapi ile kombine } \\
\text { edilmiş) }\end{array}$ & İL-2 $\leftrightarrow$ \\
\hline Zeppegno ve ark. 2021 & $\begin{array}{l}\text { Depresif belirtiler/anksiyete } \\
\text { belirtileri }\end{array}$ & Müzik destekli psikoterapi & $\begin{array}{l}\text { İL- } 6 \leftrightarrow \\
\text { TNF- } \alpha \leftrightarrow \\
\text { CRP } \leftrightarrow\end{array}$ \\
\hline
\end{tabular}


birlikte, bulgular değerlendirilirken her ne kadar tanı grupları açısından çalışmalar arasında benzerlikler olsa da örneklem özelliklerinin ve tercih edilen psikoterapi yaklaşımlarının farklı olduğu ve bu nedenle bulguların geneliyle ilgili çıkarım yapmanın güç olabileceği göz önünde bulundurulmalıdır. Özellikle örneklem özellikleri ile ilgili olarak tedavi öncesi inflamasyon önemli bir faktör olarak öne çıkmaktadır. Alanyazındaki çalışmalar tedavi öncesinde inflamasyonun varlığının psikoterapi sonucunu olumsuz etkilediği göstermektedir (gözden geçirme için bkz. Lopresti 2017). Bu çalışmalarda genel olarak tedavi öncesinde CRP, TNF- $\alpha$ ve İL- 6 düzeyleri yüksek olan katılımcıların BDT, kabul ve kararlılık tedavisi ya da gevşeme müdahalelerinden bu düzeyleri daha düşük olan katılımcılara kıyasla daha az yarar gördükleri bildirilmiştir. $\mathrm{Bu}$ açıdan psikoterapilerin inflamasyon üzerinde ne derece etkili olduğu konusunda tedavi öncesi inflamasyonun da mutlaka göz önünde bulundurulması gerekmektedir.

\section{Tartışma}

Günümüzde psikonöroimmünoloji alanındaki çalışmaların artmasıyla psikiyatrik bozukluklar ile immün sistemin ilişkisinin incelenmesine yönelik çabaların da artmaya başladığı görülmektedir. $\mathrm{Bu}$ derleme makalesi, tüm dünyada en yaygın görülen psikiyatrik bozukluk kategorileri olan duygudurum ve anksiyete bozukluklarının ve bu bozuklukları olan bireyler ile yaygın olarak kullanılan psikoterapi yaklaşımlarının immün işlev ile ilişkisine yönelik genel bir bakış sunmayı amaçlamaktadır. Özellikle pro-inflamatuar biyobelirteçlerdeki artış nöral plastisiteyi etkileyerek yeni bozukluk epizodlarının ortaya çıkmasına neden olabileceğinden, psikoterapilerin bu biyobelirteçler ile ilişkisinin daha iyi anlaşılmasının psikiyatrik bozukluklarda remisyonun sürdürülmesi ve nüksün önlenmesine yönelik girişimlere katkı sağlayabileceği öngörülmektedir (Moreira ve ark. 2015).

Duygudurum ve anksiyete bozukluklarında İL-1, İL-2, İL-6, TNF- $\alpha$ gibi sitokinlerin; CRP gibi akut faz reaktanlarının yükseldiği ve vücutta inflamatuar bir sürecin ilerlediği bilinmektedir (örn., Krogh ve ark. 2014, Wagner ve ark. 2015). Bununla birlikte alanyazında hiçbir tekli biyobelirtecin bozuklukların anlaşılmasında yeterli düzeyde özgüllüğe ve duyarlılığa sahip olmadığına da dikkat çekilmektedir (Lopresti ve ark. 2014). Farklı psikiyatrik bozukluklarda sitokinler ile ilgili benzer bulguların varlığı da bu güçlüğü artırmaktadır. Bu nedenle çalışmalarda inflamatuar belirteçlerin ölçümünün ve saklanmasının standartlaştırılması önerilmektedir (Hou ve Baldwin 2012, Lopresti ve ark. 2014). Van Duinen ve ark. nın (2004) da altını çizdiği gibi, alanyazında çalışmaların radyoimmün test ya da ELİSA yöntemi gibi farklı ölçüm yöntemleri kullanmasının çalışmalar arasında tutarlı olmayan bulguların ortaya çıkmasıyla ilişkili olması olasıdır. Benzer şekilde çalışmalarda tanı yönteminin aynı olmadığı; bazı çalışmalarda (örn., Dahl ve ark. 2016, Moreira ve ark. 2015) standart tanı görüşmeleri ve ölçüm araçları kullanılırken bazılarında (örn., Del Grande da Silva ve ark. 2016, Koh ve Lee 2004) yalnızca uzman görüşmesi yapıldığının belirtildiği görülmektedir. $\mathrm{Bu}$ açıdan psikiyatrik bozukluklar için tanı yönteminin farklı olmasının bulgular üzerinde etkili olabileceği göz önünde bulundurulmalıdır. Ayrıca bu konuda çalışmalar tasarlanırken örneklem alt gruplarının dikkatli oluşturulması da öneriler arasındadır. Örneğin bazı psikiyatrik bozuklukların genel olarak kadınlarda daha yaygın olarak görülmesinden (Castle ve ark. 2006) dolayı, çalışma örnekleminde kadınlar oransal olarak çoğunluğu oluşturmaktadır. Cinsiyetler arasındaki hormonal farklılıklar ve sosyal desteğin azlığı gibi psikososyal risk faktörleri nedeniyle depresyon gibi bozukluklara daha yatkın olmaları inflamatuar yanıtta cinsiyet farklılıklarının gözlenmesine neden olabilmektedir (Duivis ve ark. 2013). $\mathrm{Bu}$ nedenle araştırma örneklemleri oluşturulurken cinsiyetin önemli bir değişken olabileceği göz önünde bulundurulmalıdır. Bunun yanı sıra çalışmalarda örneklem gruplarının psikopatoloji tanısı temelinde oluşturulduğu görülmektedir. Ancak tedaviye yanıtın inflamasyonun başlangıçtaki düzeyine göre farklılaşması olasıdır (Morin-Alain ve ark. 2020). Bu nedenle tedavi sonucu çalışmalarında başlangıçtaki düzeylerin kontrol edilmesinin de önemli olacağı düşünülmektedir. Alanyazındaki çalışmaların örneklemlerinin görece küçük olması bulguların genellenebilirliği ve gerçek etki boyutları konusunda soru işareti oluşturmaktadır. $\mathrm{Bu}$ nedenle gelecekteki çalışmalarda daha geniş örneklemlerin hedeflenmesinin yararlı olacağı izlenimi edinilmektedir. Ayrıca sigara kullanımı, obezite gibi sağlıklı olmayan yaşam tarzı göstergelerinin duygudurum ve anksiyete bozuklukları ile inflamasyon arasında aracı ya da karıştırıcı değişkenler olabileceği ve bu göstergelerin çoklu analizlerde kontrol edilmesinin önemli olabileceği öne sürülmektedir (Duivis ve ark. 2013, Himmerich ve ark. 2019). Bu nedenle çalışmalarda bu göstergelerin göz önünde bulundurulması önemli görünmektedir. Son olarak, bu bozukluklarda genetik belirteçlerin daha önce immün sistem ile ilişkisi ortaya konduğundan (Foldager ve ark. 2014) ülkemizde de genotip-immün sistem etkileşimine yönelik çalışmaların tekrarlanması anlamlı olacaktır.

Gelecek çalışmalarda, ayrıca, tedavi sonrası immünolojik parametrelerde değişim araştırılırken sitokin ve akut faz reaktanları dışında lökosit aktivitesi, sayıları ve alt tiplerinin dağılımı, sitokin reseptörleri, sitokinlerin gen ifadesi gibi parametrelerin de çalışmalara dahil edilmesinin önemli olduğu düşünülmektedir. Özellikle hemogram-kökenli periferik biyobelirteçlerin duygudurum bozukluklarında önemli rolü olabileceği daha önce gösterilmiştir (örn., Kirlioglu ve ark. 2019, Mazza ve ark. 2018, 2019). Bu açıdan gelecek çalışmalarda farklı biyobelirteçlere odaklanılmasının anlamlı olacağı düşünülmektedir. Ayrıca kesitsel çalışmalar dışında neden-sonuç ilişkilerinin daha net olarak anlaşılmasına yardımcı olabilecek çift kör randomize kontrollü çalışmalar ve boylamsal çalışmalar ile sinir sistemi ve immün sistem arasındaki etkileşim yönü tayin edilip yeni potansiyel terapötik hedeflerin oluşturulması gerekli görünmektedir. Ayrıca nörogörüntüleme çalışmalarının da sitokinlerin bir nedensel etken mi yoksa aracı bir değişken mi olup olmadığının belirlenmesinde yardımcı olabileceği belirtilmiştir (Valkanova ve ark. 2013).

Alanyazında inflamasyonun merkezi sinir sistemi yoluyla, psikolojik müdahaleler aracılığıyla baskılanabileceği fikri görece yakın zamanda ortaya çıkmış görünmektedir. Bu konuda yapılan 
çalışmalar merkezi sinir sistemi ile immün sistem arasındaki karşılıklı etkileşimi vurgulamaktadır. Sistemler arasındaki etkileşimin daha iyi anlaşılması yoluyla bu bozukluklara yönelik tedavi yaklaşımlarının da geliştirilmesi ya da düzenlenmesi mümkün olacaktır. Ziemssen ve Kern (2007) gelecekte belirli bozuklukların ilerlemesiyle ilişkili olan fizyolojik parametreleri değiştirme becerisi temelinde belirli psikolojik müdahalelerin seçilmesinin mümkün olabileceğini belirtmektedir. Bu açıdan psikonöroimmünoloji alanında psikiyatrik bozukluklarla ilişkili fizyolojik süreçlere ve bu süreçleri değiştirme kapasitesine sahip psikoterapi müdahalelerine yönelik yapılacak çalışmaların bu bozuklukların tedavisine önemli katkı sağlayacağı öngörülmektedir.

\section{Sonuç}

Duygudurum ve anksiyete bozukluklarının birtakım immünolojik değişimlerle ilişkili olduğu görülmektedir. Bu bozukluklarda uygulanan sağaltıcı yaklaşımların gözlenen yüksek sitokin düzeylerinin gerilemesine ve dolasiyla inflamasyonun baskılanmasına yardımcı olduğu düşünülmektedir. Daha önce belirtildiği üzere, psikiyatrik semptomatolojinin immün sistem ile karşılıklı ilişkisinin aydınlatılmasının, tedavi modalitelerinin yeniden düzenlenmesinin önünü açabileceği düşünülmektedir. Alanyazındaki çalışmaların birçoğunun bozukluk ve kontrol gruplarının kıyaslanması yoluyla yapıldığı ve bu çalışmalarda belirtilerin odak olmadığı göz önünde bulundurulduğunda Duivis ve ark. nın (2013) çalışmasında olduğu gibi belirli parametrelerin belirtilerin türü ve şiddeti ile ilişkisinin inceleneceği çalışmalar da tedavi planlamasına önemli ölçüde yardımcı olacaktır. Ayrıca immünolojik parametrelerin psikoterapi yaklaşımlarının etkililiğinin değerlendirmesinde yeni bir ölçüt adayı olabileceği gibi farmakoterapilerin de immünmodülasyon özelliklerine göre seçilmesinin söz konusu olabileceği öngörülmektedir. Halihazırda merkezi sinir sistemi ilaçlarının primer etki mekanizmalarının yanında nöroinflamasyonu baskılayan nitelikte olması farmakoterapilerin başarısı adına önemli bir avantaj gibi görünmekte ve antidepresanların, duygudurum düzenleyicilerin ve anksiyolitiklerin olası anti-inflamatuar etkileriyle ilgili çalışmaların sayısı giderek artmaktadır (örn., Gałecki ve ark. 2018, Fruscella ve ark. 2001, Nassar ve Azab 2014). Gelecekte bu alanda çalışmaların sürdürülmesi önemli görünmektedir. Bununla birlikte depresif belirtiler üzerinde etkili olan tüm antidepresanların pro-inflamatuar sitokin düzeylerini azaltmada etkili olmadıkları bilindiğinden (Hannestad ve ark. 2011) gelecekte farklı farmakoterapilerin immünolojik parametreler ile ilişkisinin ayrıntılı inceleneceği çalışmalara ihtiyaç duyulmaktadır. Ayrıca anti-inflamatuar etkili ilaçların duygudurum ve anksiyete bozukluklarında primer ya da adjuvan tedavi olarak kullanılabilmesi gündeme gelmektedir (BertholdLosleben ve ark. 2009, Sartorive Singewald 2019). İnflamasyonun varlığında psikiyatrik bozukluklar ve inflamasyonun eş zamanlı tedavi edilmesinin iyileşmeyi hızlandıracağı ve bozukluğun tekrar etme riskini azaltacağı öne sürülmektedir (Kiecolt-Glaser ve ark. 2015). Bu açıdan anti-inflamatuar ilaçların duygudurum ve anksiyete bozukluklarında endikasyon kazanması ve doz belirlenmesi için klinik ilaç çalışmalarının yürütülmesinin psikiyatrik bozuklukların tedavisinin geliştirilmesi açısından anlamlı olacağı izlenimi edinilmektedir. Günümüzde doğrudan sitokin reseptörlerine bağlanan ve daha az yan etkisi olan monoklonal antikorların geliştirilmesine yönelik çalışmaların devam ediyor olması (Himmerich ve ark. 2019) bu açıdan umut verici görünmektedir. Psikoterapiler açısından ise, Lopresti'nin (2017) de belirttiği gibi, her ne kadar BDT'nin anti-inflamatuar etkileri olsa da bu değişimlerin bu terapi yaklaşımına özgü olup olmadığının anlaşılmasında farklı psikoterapi yaklaşımlarının kullanıldığı durumlarda immünolojik parametrelerde değişim gözlenip gözlenmediğinin incelenmesi yararlı olacaktır. Bunlara ek olarak, psikoterapilerin ve değişim sürecinin kültürel bağlamdan bağımsız olmadığı (Wampold 2007) düşünüldüğünde, bu tür sonuç çalışmalarının ülkemizde de tekrarlanması önerilmektedir.

Yazarların Katkıları: Yazarlar çalışmaya önemli bir bilimsel katkı sağladıklarını ve makalenin hazırlanmasında veya gözden geçirilmesinde yardımcı olduğunu kabul etmiştir.

Danışman Değerlendirmesi: Dış bağımsız.

Çıkar Çatışması: Yazarlar çıkar çatışması bildirmemiştir.

Finansal Destek: Yazarlar bu çalışma için finansal destek almadığını beyan etmiştir.

Authors Contributions: The authors attest that she has made an important scientific contribution to the study and has assisted with the drafting or revising of the manuscript.

Peer-review: Externally peer-reviewed.

Conflict of Interest: No conflict of interest was declared by the authors. Financial Disclosure: The authors declared that this study has received no financial support.

\section{Kaynaklar}

Ader R, Cohen N (1975) Behaviorally conditioned immunosuppression. Psychosom Med, 37:333-340.

Altamura AC, Buoli M, Pozzoli S (2014) Role of immunological factors in the pathophysiology and diagnosis of bipolar disorder: comparison with schizophrenia. Psychiatry Clin Neurosci, 68:21-36.

American Psychiatric Association (2013) Diagnostic and Statistical Manual Of Mental Disorders, 5th ed. Arlington, VA, American Psychiatric Association.

Amerikan Psikoloji Birliği (2021) Psychological treatments. Available from: URL:https://div12.org/psychological-treatments Accessed date:21.05.2021.

Anthony IC, Ramage SN, Carnie FW, Simmonds P, Bell JE (2005) Influence of HAART on HIV-related CNS disease and neuroinflammation. J Neuropathol Exp Neurol, 64:529-536.

Aslan Ş (2018) Tek atak ve tekrarlayan depresyon tanılı hastalarda total antioksidan seviyesi (tas), total oksidan seviyesi (tos) ve sitokin düzeylerinin karşılaştırılması ile ilaç etkisinin değerlendirilmesi (Uzmanlık tezi). Denizli, Pamukkale Üniversitesi.

Barbosa IG, Machado-Vieira R, Soares JC, Teixeira AL (2014) The immunology of bipolar disorder. Neuroimmunomodulation, 21:117-122.

Beishuizen A, Thijs LG (2003) Endotoxin and the hypothalamo-pituitaryadrenal (HPA) axis. J Endotoxin Res, 9:3-24.

Berthold-Losleben M, Heitmann S, Himmerich H (2009) Anti-inflammatory drugs in psychiatry. Inflamm Allergy Drug Targets, 8:266-276. 
Boorman E, Romano GF, Russell A, Mondelli V, Pariante CM (2015) Are mood and anxiety disorders inflammatory diseases? Psychiatric Ann, $45: 240-248$

Brietzke E, Stertz L, Fernandes BS, Kauer-Sant'Anna M, Mascarenhas M, Vargas AE et al. (2009) Comparison of cytokine levels in depressed, manic and euthymic patients with bipolar disorder. J Affect Disord, 116:214-217.

Castle DJ, Kulkarni J, Abel KM (2006) Mood and anxiety disorders in women. Cambridge, Cambridge University Press.

Choi KW, Jang EH, Kim AY, Kim H, Park MJ, Byun S et al. (2021) Predictive inflammatory biomarkers for change in suicidal ideation in major depressive disorder and panic disorder: A 12-week follow-up study. J Psychiatr Res, 133:73-81.

Comai S, Bertazzo A, Vachon J, Daigle M, Toupin J, Côté G et al. (2016) Tryptophan via serotonin/kynurenine pathways abnormalities in a large cohort of aggressive inmates: markers for aggression. Prog Neuropsychopharmacol Biol Psychiatry, 70:708-716.

Costello H, Gould RL, Abrol E, Howard R (2019) Systematic review and metaanalysis of the association between peripheral inflammatory cytokines and generalised anxiety disorder. BMJ Open, 9:e027925.

Craighead WE, Miklowitz DJ, Craighead LW (2017) Psychopathology: history, diagnosis, and empirical foundations, 3rd ed. Hoboken, New Jersey, John Wiley \& Sons.

Cristea IA, Karyotaki E, Hollon SD, Cuijpers P, Gentili C (2019) Biological markers evaluated in randomized trials of psychological treatments for depression: a systematic review and meta-analysis. Neurosci Biobehav Rev, 101:32-44.

Çavlin, A. (2017) Ulusal Hastalık Yükü Çalıșması 2013 (UHYÇ-2013). Ulusal Hastalık Yükü Çalışması Sonuçları ve Çözüm Önerileri:18. Apr 18 2017, Ankara, Hacettepe Üniversitesi Tip Fakültesi.

Dahl J, Ormstad H, Aass HCD, Malt UF, Bendz LT, Sandvik L ve ark (2014) The plasma levels of various cytokines are increased during ongoing depression and are reduced to normal levels after recovery. Psychoneuroendocrinology, 45:77-86.

Dahl J, Ormstad H, Aass HCD, Sandvik L, Malt UF, Andreassen OA (2016) Recovery from major depressive disorder episode after non邓pharmacological treatment is associated with normalized cytokine levels. Acta Psychiatr Scand, 134:40-47.

Dantzer R, Aubert A, Bluthe RM, Gheusi G, Cremona S, Laye S et al. (1999a) Mechanisms of the behavioural effects of cytokines. In Cytokines, Stress, and Depression (Eds R Dantzer, EE Wollman, R Yirmiya):83-105. New York, NY, Springer.

Dantzer R, Wollman EE, Vitkovic L, Yirmiya R (1999b) Cytokines, stress, and depression. In Cytokines, Stress, and Depression (Eds R Dantzer, EE Wollman, R Yirmiya):317-329. New York, NY, Springer.

Daruna JH (2012) Introduction to Psychoneuroimmunology, 2nd ed. San Diego, Elsevier Academic Press.

Deczkowska A, Baruch K, Schwartz M (2016) Type I/II interferon balance in the regulation of brain physiology and pathology. Trends Immunol, 37:181192.

Del Grande da Silva G, Wiener CD, Barbosa LP, Araujo JMG, Molina ML, San Martin P et al. (2016) Pro-inflammatory cytokines and psychotherapy in depression: Results from a randomized clinical trial. J Psychiatr Res, 75:57-64.

Dowlati Y, Herrmann N, Swardfager W, Liu H, Sham L, Reim EK et al. (2010) A meta-analysis of cytokines in major depression. Biol Psychiatry, 67:446-457.

Duivis HE, Vogelzangs N, Kupper N, de Jonge P, Penninx BWJH (2013) Differential association of somatic and cognitive symptoms of depression and anxiety with inflammation: findings from the Netherlands Study of Depression and Anxiety (NESDA). Psychoneuroendocrinology, 38:15731585.

Eisendrath SJ, Gillung E, Hartzler A, James-Myers M, Wolkowitz O (2016) Mindfulness-based cognitive therapy associated with decreases in c-reactive protein in major depressive disorder: a pilot study. Journal of Alternative Complementary \& Integrative Medicine, doi: 10.24966/ACIM$7562 / 100010$

Ekdahl CT (2012) Microglial activation-tuning and pruning adult neurogenesis. Front Pharmacol, 3:41.

Etkin A, Pittenger C, Polan HJ, Kandel ER (2005) Toward a neurobiology of psychotherapy: basic science and clinical applications. J Neuropsychiatry Clin Neurosci, 17:145-158

Euteneuer F, Dannehl K, Del Rey A, Engler H, Schedlowski M, Rief W (2017) Immunological effects of behavioral activation with exercise in major depression: An exploratory randomized controlled trial. Transl Psychiatry, 7:e1132.

Fedoce ADG, Ferreira F, Bota RG, Bonet-Costa V, Sun PY, Davies KJ (2018) The role of oxidative stress in anxiety disorder: cause or consequence? Free Radic Res, 52:737-750.

Fiedorowicz J (2019) Changes in inflammation with treatment for bipolar II depression: pilot trial data on differential effects of psychotherapy and medication. Neurol Psychiatry Brain Res, 33:112-118.

Foldager L, Kohler O, Steffensen R, Thiel S, Kristensen AS, Jensenius JC, Mors O (2014) Bipolar and panic disorders may be associated with hereditary defects in the innate immune system. J Affect Disord, 164:148-154.

Fruscella P, Sottocorno M, Di Braccio M, Diomede L, Piccardi N, Cagnotto A et al. (2001) 1,5-Benzodiazepine tricyclic derivatives exerting anti-inflammatory effects in mice by inhibiting interleukin- 6 and prostaglandinE(2) production. Pharmacol Res, 43:445-451.

Fuchs T (2004) Neurobiology and psychotherapy: An emerging dialogue. Curr Opin Psychiatry, 17:479-485.

Gałecki P, Mossakowska-Wójcik J, Talarowska M (2018) The antiinflammatory mechanism of antidepressants-SSRIs, SNRIs. Prog Neuropsychopharmacol Biol Psychiatry, 80:291-294.

Gazal M, Souza LD, Fucolo BA, Wiener CD, Silva RA, Pinheiro RT et al. (2013) The impact of cognitive behavioral therapy on IL- 6 levels in unmedicated women experiencing the first episode of depression: a pilot study. Psychiatry Res, 209:742-745.

GBD 2017 Causes of Death Collaborators (2018) Global, regional, and national age-sex-specific mortality for 282 causes of death in 195 countries and territories, 1980-2017: a systematic analysis for the Global Burden of Disease Study 2017. Lancet, 392:1736-1788.

Global Burden of Disease Collaborative Network (2021) Global Burden of Disease Study 2019 (GBD 2019). Seattle, USA, Institute for Health Metrics and Evaluation (IHME).

Harley J, Luty S, Carter J, Mulder R, Joyce P (2010) Elevated C-reactive protein in depression: a predictor of good long-term outcome with antidepressants and poor outcome with psychotherapy. J Psychopharmacol, 24:625-626

Hannestad J, DellaGioia N, Bloch M (2011) The effect of antidepressant medication treatment on serum levels of inflammatory cytokines: a metaanalysis. Neuropsychopharmacol, 36:2452-2459.

Harrison NA, Brydon L, Walker C, Gray MA, Steptoe A, Critchley HD (2009) Inflammation causes mood changes through alterations in subgenual cingulate activity and mesolimbic connectivity. Biol Psychiatry, 66:407-414.

Heneka MT, Carson MJ, El Khoury J, Landreth GE, Brosseron F, Feinstein DL et al. (2015) Neuroinflammation in Alzheimer's disease. Lancet Neurol, 14:388-405 
Himmerich H, Patsalos O, Lichtblau N, Ibrahim MAA, Dalton B (2019) Cytokine research in depression: principles, challenges, and open questions. Front Psychiatry, 10:30.

Hirsch EC, Vyas S, Hunot S (2012) Neuroinflammation in Parkinson's disease. Parkinsonism Relat Disord, 18:210-212.

Hofmann SG, Sawyer AT, Fang A, Asnaani A (2012) Emotion dysregulation model of mood and anxiety disorders. Depress Anxiety, 29:406-416.

Hoge EA, Brandstetter K, Moshier S, Pollack MH, Wong KK, Simon NM (2009) Broad spectrum of cytokine abnormalities in panic disorder and posttraumatic stress disorder. Depress Anxiety, 26:447-455.

Hoge EA, Bui E, Palitz SA, Schwarz NR, Owens ME, Johnston JM et al. (2018) The effect of mindfulness meditation training on biological acute stress responses in generalized anxiety disorder. Psychiatry Res, 262:328-332.

Hooley JM, Butcher JN, Nock MK, Mineka S (2017) Abnormal Psychology, 17th ed. Sussex, England, Pearson Education Limited.

Hou R, Baldwin DS (2012) A neuroimmunological perspective on anxiety disorders. Hum Psychopharmacol, 27:6-14.

Hovatta I, Juhila J, Donner J (2010) Oxidative stress in anxiety and comorbid disorders. Neurosci Res, 68:261-275.

Kalelioglu T, Genc A, Karamustafalığlu N (2017) İki uçlu bozukluk ve inflamasyon. Journal of Mood Disorders, 7:54-64.

Kalsi N, Altavilla D, Tambelli R, Aceto P, Trentini C, Di Giorgio C et al. (2017) Neural correlates of outcome of the psychotherapy compared to antidepressant therapy in anxiety and depression disorders: A metaanalysis. Front Psychol, 8:927.

Karabulut S, Taşdemir İ, Akcan U, Küçükali Cİ, Tüzün E, Çakır S (2019) Erken evre ve kronik bipolar bozukluk hastalarında inflamasyon ve nörodejenerasyon bulguları. Turk Psikiyatri Derg, 30:75-81.

Kauer-Sant'Anna M, Kapczinski F, Andreazza AC, Bond DJ, Lam RW, Young LT et al. (2009) Brain-derived neurotrophic factor and inflammatory markers in patients with early-vs. late-stage bipolar disorder. Int $\mathrm{J}$ Neuropsychopharmacol, 12:447-458.

Kaufman J, Charney D (2000) Comorbidity of mood and anxiety disorders. Depress Anxiety, 12:69-76.

Keri S, Szabo C, Kelemen O (2014) Expression of Toll-Like Receptors in peripheral blood mononuclear cells and response to cognitive behavioral therapy in major depressive disorder. Brain Behav Immun, 40:235-243.

Kiecolt-Glaser JK, Derry HM, Fagundes CP (2015) Inflammation: depression fans the flames and feasts on the heat. Am J Psychiatry, 172:1075-1091.

Kiecolt-Glaser JK, Glaser R (1992) Psychoneuroimmunology: can psychological interventions modulate immunity? J Consult Clin Psychol, 60:569-575.

Kiecolt-Glaser JK, McGuire L, Robles TF, Glaser R (2002) Psychoneuroimmunology: psychological influences on immune function and health. J Consult Clin Psychol, 70:537-547.

Kirlioglu, SS, Balcioglu, YH, Kalelioglu T, Erten E, Karamustafalioglu N (2019) Comparison of the complete blood count-derived inflammatory markers in bipolar patients with manic and mixed episodes. Bratisl Lek Listy, 120:195-199.

Klimov VV (2019) From basic to clinical immunology. Switzerland, Springer International Publishing.

Koh KB, Lee Y (2004) Reduced anxiety level by therapeutic interventions and cell-mediated immunity in panic disorder patients. Psychother Psychosom, 73:286-292
Krogh J, Benros ME, Jørgensen MB, Vesterager L, Elfving B, Nordentoft M (2014) The association between depressive symptoms, cognitive function, and inflammation in major depression. Brain Behav Immun, 35:70-76.

Lee STH (2020) Inflammation, depression, and anxiety disorder: a population-based study examining the association between Interleukin-6 and the experiencing of depressive and anxiety symptoms. Psychiatry Res, 285:112809.

Leonard BE (2010) The concept of depression as a dysfunction of the immune system. In Depression: from psychopathology to pharmacotherapy. (Eds JF Cryan, BE Leonard):53-71. Basel, Karger.

Liukkonen T, Räsänen P, Jokelainen J, Leinonen M, Järvelin MR, MeyerRochow V et al. (2011) The association between anxiety and C-reactive protein (CRP) levels: results from the Northern Finland 1966 birth cohort study. Eur Psychiatry, 26:363-369.

Lopresti AL (2017) Cognitive behaviour therapy and inflammation: a systematic review of its relationship and the potential implications for the treatment of depression. Aust N Z J Psychiatry, 51:565-582.

Lopresti AL, Maker GL, Hood SD, Drummond PD (2014) A review of peripheral biomarkers in major depression: the potential of inflammatory and oxidative stress biomarkers. Prog Neuropsychopharmacol Biol Psychiatry, 48:102-111.

Manassis K, Bradley SJ (1994) The development of childhood anxiety disorders: toward an integrated model. J Appl Dev Psychol, 15:345-366.

Mándi Y, László V (2012) The kynurenine system and immunoregulation. J Neural Transm, 119:197-209.

Mazza MG, Lucchi S, Tringali AGM, Rossetti A, Botti ER, Clerici M (2018) Neutrophil/lymphocyte ratio and platelet/lymphocyte ratio in mood disorders: A meta-analysis. Prog Neuropsychopharmacol Biol Psychiatry, 84:229-236

Mazza, MG, Tringali AGM, Rossetti A, Botti RE, Clerici, M (2019) Crosssectional study of neutrophil-lymphocyte, platelet-lymphocyte and monocyte-lymphocyte ratios in mood disorders. Gen Hosp Psychiatry, 58:712.

Memon AA, Sundquist K, Ahmad A, Wang X, Hedelius A, Sundquist J (2017) Role of IL-8, CRP and epidermal growth factor in depression and anxiety patients treated with mindfulness-based therapy or cognitive behavioral therapy in primary health care. Psychiatry Res, 254:311-316.

Messina I, Sambin M, Palmieri A, Viviani R (2013) Neural correlates of psychotherapy in anxiety and depression: a meta-analysis. PLoS One, 8:e74657.

Moreira FP, de Azevedo Cardoso T, Mondin TC, de Mattos Souza LD, Silva R, Jansen K et al. (2015) The effect of proinflammatory cytokines in Cognitive Behavioral Therapy. J Neuroimmunol, 285:143-146.

Morin-Alain V, Larouche E, Chouinard AM, Audet MC, Goulet S, Rousseau LS et al. (2020). Effects of a mindfulness-based intervention on circulating cytokine levels in individuals with amnestic mild cognitive impairment: a pilot study. OBM Integrative and Complementary Medicine, 5:1-24.

Myint AM (2013) Inflammation, neurotoxins and psychiatric disorders. Inflammation in Psychiatry, 28:61-74.

Najjar S, Pearlman DM, Alper K, Najjar A, Devinsky O (2013) Neuroinflammation and psychiatric illness. J. Neuroinflammation, 10:1-24

Nassar A, Azab AN (2014) Effects of lithium on inflammation. ACS Chem Neurosci, 5:451-458.

Olness K, Ader R (1992) Conditioning as an adjunct in the pharmacotherapy of lupus erythematosus. J Dev Behav Pediatr, 13:124-125.

Özen ME, Örüm MH, Yılmaz MB, Kalenderoğlu A (2019) İnflamatuar biyobelirteçler açısından bipolar bozukluk tip 1 tanılı hastaların sağlıklı 
kontrollerle karşılaştııılması. Adıyaman Üniversitesi Sağlık Bilimleri Dergisi, 5:1352-1360.

Paradise MB, Naismith SL, Norrie LM, Graeber MB, Hickie IB (2012) The role of glia in late-life depression. Int Psychogeriatr, 24:1878-1890.

Parekh R, Givon L (2019) American Psychiatric Association: What is psychotherapy? https://www.psychiatry.org/patients-families/ psychotherapy (Accessed 28.07.2021)

Park KM, Bowers WJ (2010) Tumor necrosis factor-alpha mediated signaling in neuronal homeostasis and dysfunction. Cell Signal, 22:977-983.

Petrowski K, Wichmann S, Kirschbaum C (2018) Stress-induced pro- and antiinflammatory cytokine concentrations in panic disorder patients. Psychoneuroendocrinology, 94:31-37.

Punchard NA, Whelan CJ, Adcock I (2004) The journal of inflammation. J Inflamm, 1:1.

Quagliato LA, Nardi AE (2018) Cytokine alterations in panic disorder: A systematic review. J Affect Disord, 228:91-96.

Raison CL, Miller AH (2003) When not enough is too much: the role of insufficient glucocorticoid signaling in the pathophysiology of stress-related disorders. Am J Psychiatry, 160:1554-1565.

Ressler K, Mayberg H (2007) Targeting abnormal neural circuits in mood and anxiety disorders: from the laboratory to the clinic. Nat Neurosci, 10:1116-1124.

Rosenberg GA (2002) Matrix metalloproteinases and neuroinflammation in multiple sclerosis. Neuroscientist, 8:586-595.

Rosenblat JD, Cha DS, Mansur RB, McIntyre RS (2014) Inflamed moods: a review of the interactions between inflammation and mood disorders. Prog Neuropsychopharmacol Biol Psychiatry, 53:23-34.

Sartori SB, Singewald N (2019) Novel pharmacological targets in drug development for the treatment of anxiety and anxiety-related disorders. Pharmacology \& Therapeutics, 204:107402.

Schiele MA, Gottschalk MG, Domschke K (2020) The applied implications of epigenetics in anxiety, affective and stress-related disorders - a review and synthesis on psychosocial stress, psychotherapy and prevention. Clin Psychol Rev, 77:101830.

Shields GS, Spahr CM, Slavich GM (2020) Psychosocial interventions and immune system function: a systematic review and meta-analysis of randomized clinical trials. JAMA Psychiatry, 77:1031-1043.

Sözeri Varma G (2014) Major depresif bozuklukta nöroinflamatuvar hipotez. Psikiyatride Güncel Yaklaşımlar, 6:1-9.

Stertz L, Magalhaes PV, Kapczinski F (2013) Is bipolar disorder an inflammatory condition? The relevance of microglial activation. Curr Opin Psychiatry, 26:19-26.

Straub J, Plener PL, Sproeber N, Sprenger L, Koelch MG, Groen G, Abler
B (2015) Neural correlates of successful psychotherapy of depression in adolescents. J Affect Disord, 183:239-246.

Tükel, R, Arslan BA, Ertekin BA, Ertekin E, Oflaz S, Ergen A et al. (2012) Decreased IFN- $\gamma$ and IL-12 levels in panic disorder. J. Psychosomatic Res, 73:63-67.

Van Duinen M, Schruers K, Griez E, Maes M (2004) Neuroimmunological parameters in panic disorder. Acta Neuropsychiatrica, 16:94-100.

Valkanova V, Ebmeier KP, Allan CL (2013) CRP, IL-6, and depression: a systematic review and meta-analysis of longitudinal studies. J Affect Disord, 150:736-744.

Vojvodic J, Mihajlovic G, Vojvodic P, Radomirovic D, Vojvodic A, Vlaskovic Jovicevic $\mathrm{T}$ et al. (2019) The impact of immunological factors on depression treatment - relation between antidepressants and immunomodulation agents. Open Access Maced J Med Sci, 7:3064-3069.

Vogelzangs N, Beekman ATF, De Jonge P, Penninx BWJH (2013) Anxiety disorders and inflammation in a large adult cohort. Transl Psychiatry, 3:e249.

Wagner EYN, Wagner JT, Glaus J, Vandeleur CL, Castelao E, Strippoli MPF et al. (2015) Evidence for chronic low-grade systemic inflammation in individuals with agoraphobia from a population-based prospective study. PLoS One, 10:e0123757.

Walsh E, Eisenlohr-Moul T, Baer R (2016) Brief mindfulness training reduces salivary IL-6 and TNF- $\alpha$ in young women with depressive symptomatology. J Consult Clin Psychol, 84:887-897.

Wampold BE (2007) Psychotherapy: The humanistic (and effective) treatment. Am Psychol, 62:857-873.

Watson D (2005) Rethinking the mood and anxiety disorders: a quantitative hierarchical model for DSM-V. J Abnorm Psychol, 114:522-536.

World Health Organization (2017) Depression and Other Common Mental Disorders: Global Health Estimates. Geneva, World Health Organization.

Yoon HK, Kim YK, Lee HJ, Kwon DY, Kim L (2012) Role of cytokines in atypical depression. Nord J Psychiatry, 66:183-188.

Yuan N, Chen Y, Xia Y, Dai J, Liu C (2019) Inflammation-related biomarkers in major psychiatric disorders: a cross-disorder assessment of reproducibility and specificity in 43 meta-analyses. Transl Psychiatry, 9:233.

Zeppegno P, Krengli M, Ferrante D, Bagnati M, Burgio V, Farruggio $S$ et al. (2021) Psychotherapy with music intervention improves anxiety, depression and the redox status in breast cancer patients undergoing radiotherapy: a randomized controlled clinical trial. Cancers, 13:1752.

Ziemssen T, Kern S (2007) Psychoneuroimmunology-cross-talk between the immune and nervous systems. J Neurol, 254:II8-II11.

Zou Z, Zhou B, Huang Y, Wang J, Min W, Li T (2020) Differences in cytokines between patients with generalised anxiety disorder and panic disorder. J Psychosom Res, 133:109975 